\title{
BELGRANDIELLA A. J. WAGNER, 1928 (CAENOGASTROPODA: TRUNCATELLOIDEA: HYDROBIIDAE): HOW MANY ENDEMICS?
}

\author{
ANDRZEJ FALNIOWSKI ${ }^{1}$, LUBOŠ BERAN ${ }^{2}$ \\ ${ }^{1}$ Department of Malacology, Institute of Zoology, Jagiellonian University, Gronostajowa 9, 30-387 Cracow, \\ Poland (e-mail: andrzej.falniowski@uj.edu.pl) \\ ${ }^{2}$ Nature Conservation Agency of the Czech Republic, Regional Office Kokořínsko - Máchův kraj Protected \\ Landscape Area Administration, Česká 149, CZ - 27601 Mělník, Czech Republic (e-mail: lubos.beran@ \\ nature.cz)
}

ABSTRACT: Three species of the genus Belgrandiella A. J. Wagner, 1928 and Boleana umbilicata (Kuščer, 1932) from springs in Slovenia and Croatia were used for this study. All of them were originally described based on minor differences in shell morphology. Molecular data showed only small differences among all the nominal taxa, typical of intrapopulation variation. COI sequences of Boleana umbilicata and Belgrandiella kusceri were identical, and Boleana should be synonymised with Belgrandiella. The molecular data strongly suggest that all four nominal species represent one biological entity - a genetically variable species.

KEY WORDS: DNA, genetic distance, COI, Boleana

\section{INTRODUCTION}

The truncatelloidean fauna of the Balkans is represented by numerous genera, many of them represented by many species (SZAROWSKA 2006). Undoubtedly, it is one of the two species-richest areas in Europe. The long-term studies in the former Yugoslavia (RADOMAN 1973, 1975, 1976, 1983, 1985) resulted in a long list of species and genera. The vast majority of those snails inhabit springs, potentially isolated habitats, and thus high levels of endemism could be expected. This resulted in a high number of species, although not all of them were the real biological entities. In fact, apart from distribution, usually only the shell characters were considered, but the shell in the Truncatelloidea is both poor in taxonomically useful characters, and highly variable. Thus, the species distinctness of the majority of those endemics remains an open question.

One of the hot spots in the region is the river Zrmanja in Croatia, $69 \mathrm{~km}$ long, its catchment area covering $907 \mathrm{~km}^{2}$; it is one of the European diversity hot spots of freshwater gastropods. It is inhabited by 16 (five of them endemic, STRONG et al. 2008) or 22 species (BERAN 2011). The Truncatelloidea are represented by three species found in the brackish water part below the Jankovica Buk waterfalls, and by eight species in the freshwater part above Jankovica Buk. Four of the freshwater species: Belgrandiella krupensis Radoman, 1973, B. zermanica Radoman, 1973, Islamia zermanica Radoman, 1973, and Tanousia zrmanjae (Brusina, 1866) (= Lithoglyphulus tedanicus Schlickum et Schütt, 1971), were described from this part including its tributary, the Krupa River.

In this study we checked the distinctness of the three species of Belgrandiella A. J. Wagner, 1928, and Boleana umbilicata (Kuščer, 1932), each from the type locality, and each regarded as endemic: we reexamined their morphology, and compared their cytochrome oxidase subunit I (COI) mtDNA partial sequences. 


\section{MATERIAL AND METHODS}

The specimens were collected at the following localities (Fig. 1):

1. Močilnik near Vrhnika; the main source of the Ljubljanica River, near the road Ljubljana-Postojna, Slovenia; several huge springs forming a deep pond with a bottom of sand, gravel and rock overgrown with rich vegetation; water comes from a couple of flat, rocky pools situated a few metres above the pond; $45^{\circ} 57^{\prime} 06^{\prime \prime} \mathrm{N}, 14^{\circ} 17^{\prime} 44^{\prime \prime} \mathrm{E}, 313 \mathrm{~m}$ a.s.l.; 29.08.2001: Boleana umbilicata (Kuščer, 1932);

2. Rakovski potok [Crab stream], below Mali Naravni Most (small natural bridge) near Rakovski Skocjan, Rakek, Slovenia; a huge outlet from a big cave, all material sorted out of detritus from between rocks at the bottom of the brook; $45^{\circ} 46^{\prime} 39^{\prime \prime} \mathrm{N}$, $14^{\circ} 11^{\prime} 08^{\prime \prime}$ E, $514 \mathrm{~m}$ a.s.l.; 29.08.2001: Belgrandiella kusceri (A. J. Wagner, 1914);

3. Krupa, a small spring by the Krupa River about $140 \mathrm{~m}$ upstream of the bridge of the local road in Krupa, Croatia; $44^{\circ} 11^{\prime} 39.3^{\prime \prime} \mathrm{N}, 15^{\circ} 54^{\prime} 34.5^{\prime \prime} \mathrm{E}$; 17.08.2013: Belgrandiella krupensis Radoman, 1973;

4. Dramotići, a spring near the Zrmanja River downstream of waterfalls (left bank at a big rock, large spring overgrown by rich vegetation),

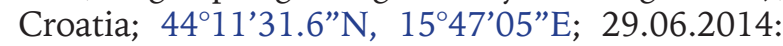
Belgrandiella zermanica Radoman, 1973.

Snails were collected by hand or with a sieve from the vegetation, stones or sediment. Individuals for molecular analyses were then washed in $80 \%$ ethanol and left to stand in it for ca. 12 hours. Afterwards, the ethanol was changed twice during 24 hours and, after a few days, $80 \%$ ethanol was replaced with $96 \%$ ethanol. The samples were then stored at $-20^{\circ} \mathrm{C}$ prior to DNA extraction.

The snails were dissected using a NIKON SMZ18 stereo-microscope with dark field, and shells and penes photographed with CANON EOS 50D digital camera.

For DNA, foot tissue was hydrated in TE buffer $(3 \times$ 10 min.); then total genomic DNA was extracted with the SHERLOCK extracting kit (A\&A Biotechnology), and the final product was dissolved in $20 \mu \mathrm{l}$ TE buffer. The PCR reaction was performed with the following primers: LCO1490 (5'-GGTCAACAAATCATAAAGATATTGG-3') (FOLMER et al. 1994) and COR722b (5'-TAAACTTCAGGGTGACCAAAAAATYA-3') (WILKE \& DAVIS 2000) for the mitochondrial cytochrome oxidase subunit I (COI) gene.

\section{RESULTS}

The shells of Boleana umbilicata (Figs 2-3) are broad, bulky, and relatively big, although in Belgrandiella kusceri (Figs 4-7) some shells are not smaller (Fig. 7).

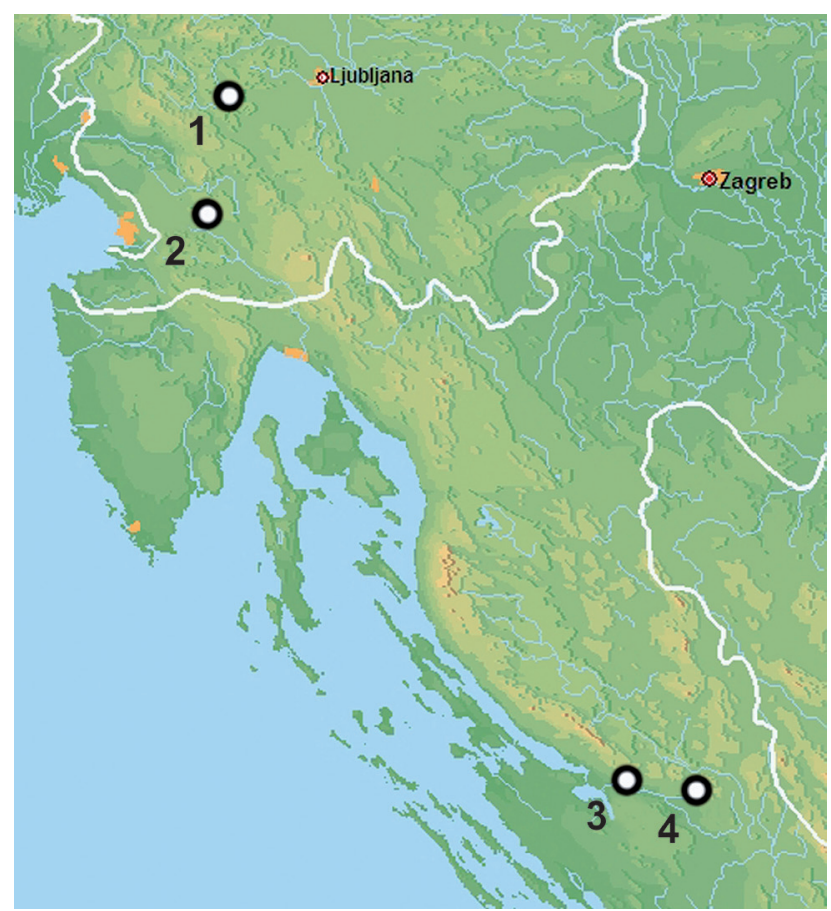

Fig. 1. Studied localities: 1 - Močilnik near Vrhnika (source of Ljubljanica River, Slovenia); 2 - Rakovski potok (below Mali Naravni Most near Rakovski Skocjan, Rakek, Slovenia); 3 - Krupa (spring of Krupa River, Croatia); 4 - Dramotići (spring of Zrmanja River, Croatia)

The PCR conditions were as follows: initial denaturation step of $4 \mathrm{~min}$ at $94^{\circ} \mathrm{C}$, followed by 35 cycles of $1 \mathrm{~min}$ at $94^{\circ} \mathrm{C}, 1 \mathrm{~min}$ at $55^{\circ} \mathrm{C} 2 \mathrm{~min}$ at $72^{\circ} \mathrm{C}$, and a final extension of $4 \mathrm{~min}$ at $72^{\circ} \mathrm{C}$. The total volume of each PCR reaction mixture was $50 \mu$ l. To check the quality of the PCR products $10 \mu \mathrm{l}$ of the PCR product was ran on $1 \%$ agarose gel. The PCR products were purified using Clean-Up columns (A\&A Biotechnology) and were then amplified in both directions using BigDye Terminator v3.1 (Applied Biosystems), following the manufacturer's protocol and with the primers described above. The sequencing reaction products were purified using ExTerminator Columns (A\&A Biotechnology); DNA sequences then underwent electrophoresis on an ABI Prism sequencer.

The COI sequences were aligned by eye using BioEdit 5.0.0 (HALl 1999). MEGA5.10 (TAMURA et al. 2011) was used to calculate pairwise p-distances, and maximum likelihood tree, applying Tamura 3-parameter model (NEI \& KUMAR 2000).

In Belgrandiella krupensis (Figs 8-11) and B. zermanica (Figs 12-15) the shells are smaller, in B. zermanica more slender than in B. krupensis. 


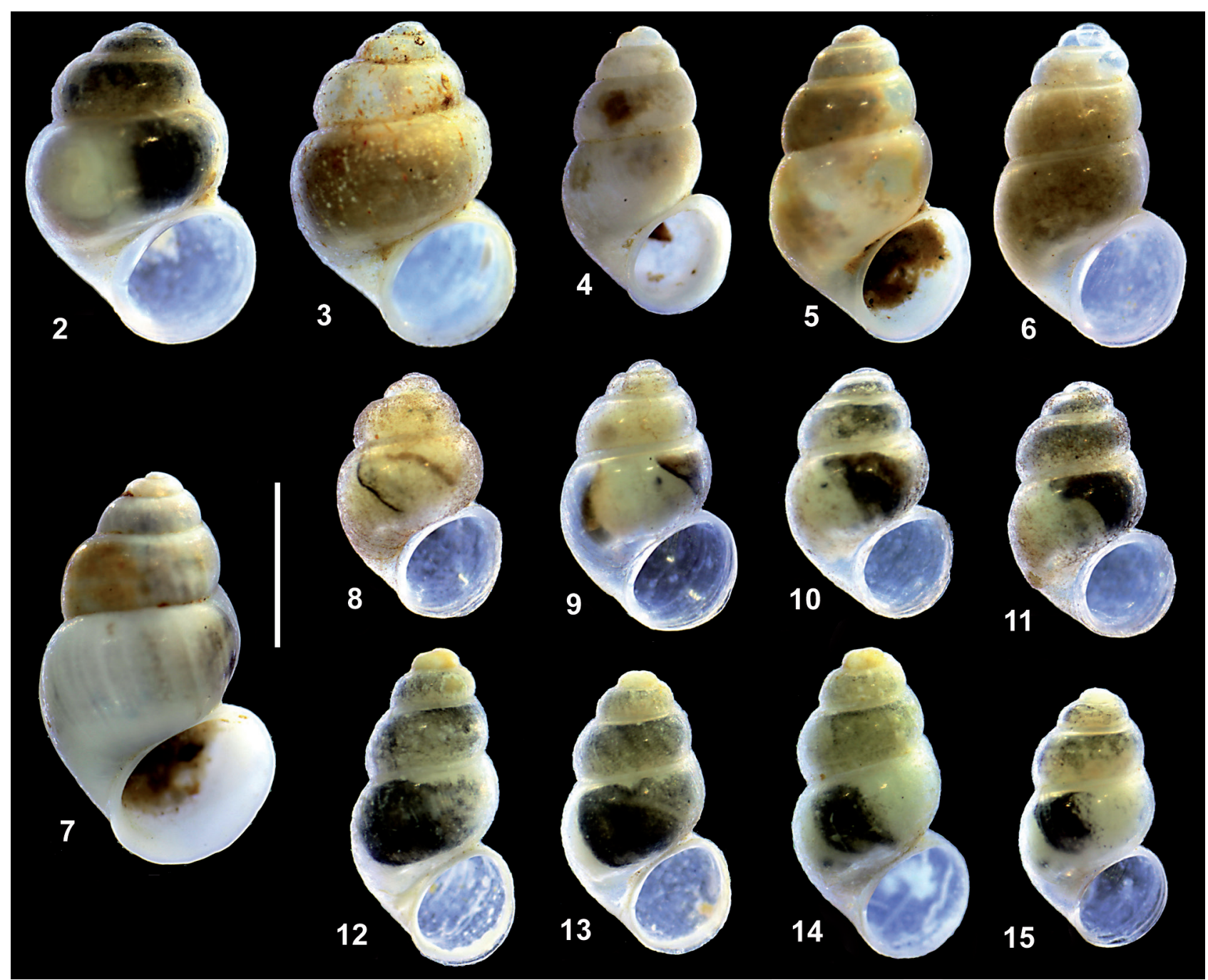

Figs 2-15. Shells of the studied nominal species: 2-3 - Boleana umbilicata, Močilnik; 4-7 - Belgrandiella kusceri, Rakovski potok; 8-11 - Belgrandiella krupensis, Krupa; 12-15 - Belgrandiella zermanica, Zrmanja

The female reproductive organs do not show any differences between the four nominal species (RADOMAN 1983, AF personal observations). The same concerns the penis in all three species of Belgrandiella. Only in Boleana it is bigger, and with a small, inconspicuous outgrowth at its left side (RADOMAN 1983, SZAROWSKA 2006).

The thirteen studied sequences (GenBank numbers KT218510-KT218521), 684 bp long, show intrapopulation differences neither in Belgrandiella

Table 1. p-distances between the studied sequences: 1-6 - Belgrandiella zermanica, 7-11 - Belgrandiella krupensis, 12 - Belgrandiella kusceri, 13 - Boleana umbilicata

\begin{tabular}{|c|c|c|c|c|c|c|c|c|c|c|c|c|c|}
\hline & 1 & 2 & 3 & 4 & 5 & 6 & 7 & 8 & 9 & 10 & 11 & 12 & 13 \\
\hline 1. $9 \mathrm{E} 10 \mathrm{X}$ & & & & & & & & & & & & & \\
\hline 2. 9E10XR & 0.0000 & & & & & & & & & & & & \\
\hline 3. $9 \mathrm{E} 10 \mathrm{R}$ & 0.0000 & 0.0000 & & & & & & & & & & & \\
\hline 4. 9E11XR & 0.0000 & 0.0000 & 0.0000 & & & & & & & & & & \\
\hline 5. $9 \mathrm{E} 11 \mathrm{X}$ & 0.0000 & 0.0000 & 0.0000 & 0.0000 & & & & & & & & & \\
\hline 6. 9E11R & 0.0000 & 0.0000 & 0.0000 & 0.0000 & 0.0000 & & & & & & & & \\
\hline 7. 9L1R & 0.0029 & 0.0029 & 0.0029 & 0.0029 & 0.0029 & 0.0029 & & & & & & & \\
\hline 8. $9 \mathrm{~L} 2 \mathrm{X}$ & 0.0029 & 0.0029 & 0.0029 & 0.0029 & 0.0029 & 0.0029 & 0.0000 & & & & & & \\
\hline 9. $9 \mathrm{~L} 3 \mathrm{X}$ & 0.0029 & 0.0029 & 0.0029 & 0.0029 & 0.0029 & 0.0029 & 0.0000 & 0.0000 & & & & & \\
\hline 10. $9 \mathrm{~L} 3 \mathrm{XR}$ & 0.0029 & 0.0029 & 0.0029 & 0.0029 & 0.0029 & 0.0029 & 0.0000 & 0.0000 & 0.0000 & & & & \\
\hline 11. 9L3R & 0.0029 & 0.0029 & 0.0029 & 0.0029 & 0.0029 & 0.0029 & 0.0000 & 0.0000 & 0.0000 & 0.0000 & & & \\
\hline 12. 9L15 & 0,0044 & 0.0044 & 0.0044 & 0.0044 & 0.0044 & 0.0044 & 0.0015 & 0.0015 & 0.0015 & 0.0015 & 0.0015 & & \\
\hline 13. 9L18 & 0.0044 & 0.0044 & 0.0044 & 0.0044 & 0.0044 & 0.0044 & 0.0015 & 0.0015 & 0.0015 & 0.0015 & 0.0015 & 0.0000 & \\
\hline
\end{tabular}




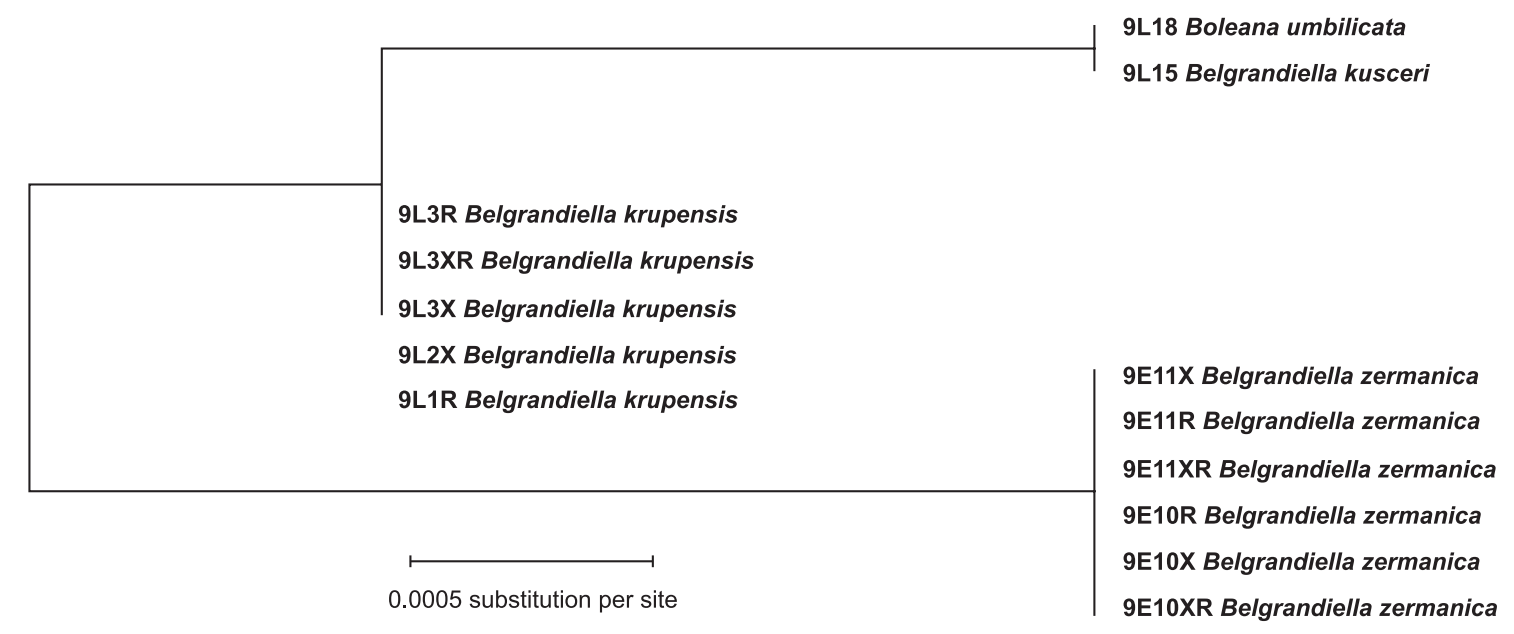

Fig. 16. Maximum likelihood tree of the studied taxa

krupensis (five sequences), nor in B. zermanica (six sequences). The p-distances between the four nominal species (Table 1) were in the range of $0.0000-0.0044$, thus were typical of intrapopulation variation. It has to be stressed that the sequences of Boleana umbilicata and Belgrandiella kusceri were identical (Fig. 16).

\section{DISCUSSION}

The high plasticity and thus intraspecific variation of the shell is commonly known, especially in the case of such minute and simple shells. Conchologically distinct but molecularly identical nominal taxa can occur sympatrically (e.g. WILKE \& FALNIOWSKI 2001) and, conversely, molecularly identical snails collected at the same locality at different times can show evident differences in their shell morphology, reflected in principal component analysis (PCA) (FALNIOWSKI et al. 2012), The shell alone cannot be the basis of species discrimination in the Truncatelloidea. However, according to RADOMAN (1983) congeneric species may not differ in their soft parts' morphology and anatomy.

In Boleana there are two pairs of basal cusps on the central tooth, although one of them vestigial, and in Belgrandiella only one pair (SZAROWSKA 2006). However, such differences can be found in several Truncatelloid species. The small lobe, or rather outgrowth on the penis of Boleana - the only morphological difference compared to Belgrandiella - need not reflect distinctness of Boleana, especially since a rudimentary lobe can be found on the penis of Belgrandiella as well. A much wider variation of the penis can be observed in e.g. Horatia klecakiana Bourguignat, 1887 (RADOMAN 1983, SZAROWSKA \& FALNIOWSKI 2014). Considering the identity of the studied sequences of Boleana umbilicata and Belgrandiella kusceri, the genus Boleana should be synonymised with Belgrandiella.

Certainly, the genetic differences in just one locus cannot definitely solve any taxonomic question at the species level. However, it is hardly imaginable that in such a fast-evolving sequence nothing has happened after a speciation event. Our molecular data strongly suggest that all four nominal species represent one real biological entity: one species, genetically slightly variable. Consequently, the real level of endemism may be much lower than it is usually assumed. The studies on this genus, as well as on other "endemic-rich" genera, should be continued.

\section{ACKNOWLEDGEMENTS}

The study was supported by a grant from the National Science Centre (2012/05/B/NZ8/00407) to MAGDALENA SZAROWSKA.

\section{REFERENCES}

BERAN L. 2011. Non-marine molluscs (Mollusca: Gastropoda, Bivalvia) of the Zrmanja River and its tributaries (Croatia). Nat. Croat. 20: 397-409.

FALNIOWSKI A., SZAROWSKA M., GLÖER P., PEŠIĆ V. 2012. Molecules vs. morphology in the taxonomy of the
Radomaniola/Grossuana group of Balkan Rissooidea (Mollusca: Caenogastropoda). J. Conchol. 41: 19-36.

Folmer O., Black M., HoEH W., Lutz R. A., VRIJENHOEK

R. C. 1994. DNA primers for amplification of mitochondrial cytochrome $\mathrm{c}$ oxidase subunit I from diverse 
metazoan invertebrates. Mol. Mar. Biol. Biotechnol. 3: 294-299.

HALl T. A. 1999. BioEdit: a user-friendly biological sequence alignment editor and analysis program for Windows 95/98/NT. Nucleic Acids Symp. Ser. 41: 9598.

Nei M., Kumar S. 2000. Molecular evolution and phylogenetics. Oxford University Press, Oxford, New York.

RADOMAN P. 1973. New classification of fresh and brackish water Prosobranchia from the Balkans and Asia Minor. Posebna Izdanja, Prirodn. Mus. Beograd 32: 1-30.

RADOMAN P. 1975. Specijacija u okviru roda Belgrandiella i njemu srodnih rodova na Balkanskom poluostrvu. Glasnik Prirodnjackog Museja, Beograd, series B 30: 29-69.

RADOMAN P. 1976. Speciation within the family Bythinellidae on the Balkans and Asia Minor. Z. Zool. Syst. Evol. 14: 130-152. http://dx.doi. org/10.1111/j.1439-0469.1976.tb00522.x

RADOMAN P. 1983. Hydrobioidea a superfamily of Prosobranchia (Gastropoda). I. Systematics. Serbian Academy of Sciences and Arts, Monographs 547, Department of Sciences 57: 1-256.

RADOMAN P. 1985. Hydrobioidea, a superfamily of Prosobranchia (Gastropoda). II. Origin, zoogeography, evolution in the Balkans and Asia Minor. Faculty of Science - Department of Biology Monographs 1, Institute of Zoology, Beograd 1: 1-173.

Strong E. E., GARgominy O., Ponder W. F., Bouchet P. 2008. Global diversity of gastropods (Gastropoda; Mollusca) in freshwater. Hydrobiologia 595: 149-166. http://dx.doi.org/10.1007/s10750-007-9012-6
SZAROWSKA M. 2006. Molecular phylogeny, systematics and morphological character evolution in the Balkan Rissooidea (Caenogastropoda). Folia Malacol. 14: 99168. http://dx.doi.org/10.12657/folmal.014.014

SZAROWSKA M., FALNIOWSKI A. 2014. Horatia Bourguignat, 1887: is this genus really phylogenetically very close to Radomaniola Szarowska, 2006 (Caenogastropoda: Truncatelloidea)? Folia Malacol. 22: 31-39. http://dx. doi.org/10.12657/folmal.022.003

Tamura K., Peterson D., Peterson N., Stecher G., NeI M., KUMAR S. 2011. MEGA5: Molecular evolutionary genetics analysis using maximum likelihood, evolutionary distance, and maximum parsimony method. Mol. Biol. Evol. 28: 2731-2739. http://dx.doi.org/10.1093/ molbev/msr121

WiLKE T., DAVIS G. M. 2000. Infraspecific mitochondrial sequence diversity in Hydrobia ulvae and Hydrobia ventrosa (Hydrobiidae: Rissoacea: Gastropoda): Do their different life histories affect biogeographic patterns and gene flow? Biol. J. Linn. Soc. 70: 89-105. http://dx.doi. org/10.1111/j.1095-8312.2000.tb00202.x

WiLKE T., FALNIOWSKI A. 2001. The genus Adriohydrobia (Hydrobiidae: Gastropoda): polytypic species or polymorphic populations? J. Zool. Syst. Evol. Res. 39: 227-234. http://dx.doi.org/10.1046/j.14390469.2001.00171.x

Received: March 3rd, 2015

Revised: May 7th, 2015

Accepted: May 25th, 2015

Published on-line: July 8th, 2015 